\title{
The Effectiveness of Integrating Local Potential on Science Process Skills and Conceptual Understanding
}

\author{
Insih Wilujeng, IGP Suryadarma \\ PPs Universitas Negeri Yogyakarta \\ Yogyakarta, Indonesia \\ insih@uny.ac.id
}

\begin{abstract}
This research aimed to find out the influence of the integration of local potential into natural science on the science process skills and the students' mastery of natural science concepts simultaneously. This research was a quasi-experiment research with non-equivalent control group design. The population in this research was the seventh-grade students of SMPN 1 Imogiri; the samples were chosen randomly and classified into a control group and an experiment group. Observation sheets and concept mastery assessments were employed as the instruments in this research. The data were analyzed using MANOVA with 0.05 significance level. The results of this research showed that the integration of local potential into natural science study significantly influenced the students' process skills and concepts simultaneously as shown in 0.00 (Sig. $>0.05$ ) output.
\end{abstract}

Keywords - science study, local potential, science process creativity, concept mastery.

\section{INTRODUCTION}

Education process is not far from sciences development; one of them is natural science. According [1], education is a systematic process that elevates human's dignity holistically and enables self-potentials (affective, cognitive, psychomotor) to develop optimally. Besides, the curriculum is arranged while considering potentials, development levels, interest, intellectual intelligence, emotionality, social, spirituality, and student's kinesthetic.

Natural science is not just about the dimension of knowledge, but it emphasizes more on the process that can be used to study the object, to discover, and to develop the natural science products, and also to decide which application that will invent technology that can give convenience towards human's life. According to [2], natural science as a research process or method includes the way of thinking, attitude, and steps of scientific activities to obtain the natural science products or scientific knowledge, for example, observation, measuring, formulating, hypothesis testing, data collecting, experimenting, and predicting. Richie and Heru [3] stated that the fact of the natural science is composed of four elements which are natural science as a process, natural science as a product, natural science as character development, and natural science as an application. The four truth of natural science has to be achieved altogether in the learning process. Those facts of the natural science can be developed; one of the possible ways is through science class.

Therefore, natural science is a bundle of knowledge built from a series of research processes to fix everyday life problems. Natural science has a method known by scientific methods, gradually covering problem identification, data collecting, hypothesis formulating, hypothesis testing, and concluding. According to [4], the goal of natural science studies education is to help the students applying the creativity of natural science process, or in other words, to be able to define the problems around them through observation, analyzing, creating hypothesis, trying, concluding, generalizing, and applying the earned information using the required skills.

Corresponding to the Graduate Competency Standards/SKL, the learning target includes developments of attitude, knowledge, and skills elaborated for every education unit [1]. Therefore, the learning process in school should be holistic, in which the learning target is not on just one aspect, but on the other two aspects as well so that the learning process will create students that are better than before.

All this time, the learning process of natural science has been pretty much telling the students off to memorize some numbers of concepts without giving them the understanding. The learning process is still lacking scientific works and more weighting on the students' ability to complete question sheets that make the students are only on the cognitive side without psychomotor and affective sides [5]. Holbrook [6] assumed that natural science is irrelevant to the students' views and will not be favored because the students are imposed on understanding basic concepts and that the basic understanding of natural science studies is not connected to the other things connected to the students' everyday living environments. Therefore, if natural science is linked to everyday living environments, the students will like the learning process of natural science that will end in giving themselves more meaningful learning experiences.

Environment integration into learning in school is truly needed so that the students will not forget their real identity and be able to develop the local potentials that are actually around them. Local potential integration into studies will elevate the students' respect towards local potential and local wisdom values in the environments where they are in so that it affects 
their learning output (attitude, habits, and thinking ability). According to [7], the use of local potential in learning materials can help the students to understand the concept correctly and contextually. Based on a research conducted by [8], learning processes based on local potential can give out better influences towards the study achievements enhancement of natural science compared to the learning process that uses regular learning model.

Indonesia is an archipelago country consisting of huge and tiny islands with the number of roughly 17.500 islands. The diversities that become Indonesia's characteristic and uniqueness, are the geographical identity, resource potential, facilities and infrastructure availability, background and sociocultural conditions, and the other more diversities in every area [1]. This phenomenon causes Indonesia to have diverse conditions and potentials, that one area has different potentials from the other areas. The diversity fosters different necessity levels and development challenges in each area to increase the quality and educate the lives of the inhabitants in every area.

The potential that is owned by one particular area is called local potential. The local potential is a specific resource owned by one area that includes natural resource potentials, human resources, geography, culture, and history. According to [9], local potential is uniqueness or specificity of an area (local) as one of the identities or one area characteristic that grows into the area potential or a plus point compared to the other areas, covering ecology aspect developed from local potentials in a form of natural resources that could educate the locals to preserve and conserve their environment. The students' learning environment in each area is definitely diverse. Based on the research done by [10], students' natural science studies process skills enhanced on a higher category (80\%) when learning is integrated with the local potential of making "batik jumputan" (batik tie-dye patterns). Therefore, the local potential is proved useful in the learning process of natural science studies.

Natural science learning should give the students chances to improve their natural science process skills. With the good process skills, students will be able to conduct high-quality scientific activities that will also produce high-quality products. By such thing, the key in natural science is to improve students' process skills. According to [11], the ability to utilize natural science process skills in overcoming everyday problems is very significant in one's personal life that is in social life rapid growth. Individuals who have natural science process skills will be able to contribute to social improvement.

Most individuals improve their skills through formal education by interacting with teachers. Therefore, teachers hold an important role in improving process skills. Teaching natural science process skills gives a chance for the students to work with science, not just telling or hearing stories about it, but students will feel happy from being active and by not being passive learners [12]. Research conducted by [13] proved that students who are accustomed to natural science knowledge have integrated natural science process skills on a higher category compared to the ones who are not used to study natural science. According to [14], natural science process skills in natural science education should be integrated into the education system. Natural science education that is applied by natural science process skills will enable the students learn the process, product, and even knowledge value. Developing natural science process skills can be optimized by learning through one precise learning device, clearly and systematically able to manifest values/characters into the curriculum, the concept, and also the skills from natural science learning itself. Learning that brings students closer to learning objects will make the learning more meaningful, for example school environments. The natural science process skills that can be improved are observation, clarification, hypothesis creation, variable decision, experiments, and communication.

Understanding the world around us depends on concept development, while concept development itself depends on process skills because concept development and process skills are related each other. Slowly, concepts will grow rapidly while process skills are sharpened [15]. Deep concept mastery can be reached by students if they are taking an active role, or being involved directly into the learning activities, especially the activities which require the students to do a direct object observation, teachers who start off as learning sources switch functions into facilitator that directs the students to independently find the concept currently being studied. If the students can apply their own knowledge into the environment around them, then it is not impossible that Indonesian education quality improves so it can compete in free competition events [9].

Based on the research conducted by [16], most teachers (100\%) had understood school local potential that is on the schoolyard and $70.59 \%$ of teachers understood the local potential that is on $1 \mathrm{~km}$ radius from the school fence but only a small portion utilizing it in the learning process. Natural science literacy achievement of Indonesian students is still far back behind the other countries. A study result [17], said that Indonesian students' natural science literacy level was on number 64 out of 65 participating countries, with an average score of 382, far under the overall's average number that reached 501 [17]. Based on the research conducted by [18], it showed that about $43.48 \%$ of middle school students in Jambi have a relatively low natural science process skills with the percentage of $30,43 \%$ on the medium category and $26.09 \%$ on the high category.

Based on the analysis above, it can be concluded that natural science learning process that can make the students taking active roles or directly involved in the learning activities, especially the activities that require the students observe objects directly and the one that can train their process skills is required to improve their concept mastery.

\section{METHODS}

The research method used in this research was quantitative research with the use of quasi-experiment method, nonequivalent control group design. The research was conducted in October 2016, at SMPN 1 Imogiri. The populations of this research were the 7th-grade students of SMPN 1 Imogiri. Sample determination was chosen through random sampling, and $7 \mathrm{~A}$ was chosen as the experiment class and $7 \mathrm{D}$ as the control class. 


\section{A. Procedure}

The procedure of this research was started off by (1) gathering preliminary data by giving a pretest assessing students' concept mastery and conducting initial observation on students' process skills (experiment and control groups), (2) giving treatment using local potential integrated natural science learning of Pembangkit Listrik Tenaga Micro Hydro (PLTMH)/Micro Hydro Power Plants on experiment group and conventional natural science learning towards the control group corresponding to the research data gathering timeline, (3) throughout the treatment, the data collection was done related to the natural science process skills from students that were on experiment and control groups using the observation sheets, (4) conducting post-tests on natural science concept mastery for the students after giving treatment.

\section{B. Technique and Data Collection Instruments}

Research instrument is the measurement tool used to obtain the necessary data in a research. Instruments that were employed in this research were written test sheets and observations sheets adapted from the results of [19] research and development that was re-validated to suit the researcher's necessity in terms of legibility without changing the essence of the developed product. The uses of both instruments are presented:

\section{1) Observation Sheet}

There were two kinds of observation sheets used in this research, namely (1) observation sheet used to find out students' natural science initial process skills before the research, and (2) observation sheet used to find out the students' natural science process skills throughout the research.

\section{2) Written Test Sheet}

The written test sheet used in this research consisted of 20 numbers of multiple choices questions of which validity had been tested. Multiple choices questions were used to measure the student's concept mastery. Before receiving a treatment of integrated the natural science learning local potential of PLTMH, the sample was first given a pre-test. The results of this pre-test were used to find out the students' initial ability in mastering basic competencies of energy material. Post-test instrument was then used to measure the students' concept mastery after being given treatment.

TABLE I. ASPECT AND SCORING INDOCATOR OF SCIENCE PROCESS SKILLS

\begin{tabular}{|l|l|}
\hline Aspect & \multicolumn{1}{|c|}{ Indicator } \\
\hline Observation & Using sense organs \\
\cline { 2 - 2 } & Gathering relevant facts \\
\hline Communication & Describing observation result in the form of tables \\
\cline { 2 - 2 } & Explaining observation result \\
\cline { 2 - 2 } & Discussing activity result \\
\hline
\end{tabular}

\section{Data Analysis Technique}

Data analysis techniques that were utilized in this research were descriptive analysis technique and inferential analysis with the help of SPSS 16.0 for windows program. Descriptive analysis was done to present natural science process skills data and students' concept mastery. Natural science process skills and students' concept mastery data presented are the average scores, the highest score, lowest score, variants, and deviation standard from experiment and control class. Then, those data were converted to the Likert scale on four categories to find out the categories of the students' process skills. The conversion of the four categories refers to the assessment guidelines by the educator that can be seen in Table 2 .

Besides descriptive analysis technique, inferential analysis technique was also executed in the research using Multivariate Analysis of Variance (MANOVA). The Manova test was employed to test the data produced from students' natural science process skills and concept mastery all at the same time. Before the Manova test was conducted, precondition test was done including normality and homogeneity tests.

Process skills improvement and overall concept mastery were analyzed using the normalized gain average score. The normalized gain average score was determined by the equation below.

\section{RESULT AND DISCUSSION}

Based on the research conducted, data of student's natural science process skills in learning can be seen in Table 3 [20].

$$
g=\frac{\text { posttest score-pretest score }}{\text { maximum score-pretest score }}
$$

TABLE II. CATEgories of Normalized Gain Average SCORE

\begin{tabular}{|l|l|l|}
\hline No. & \multicolumn{1}{|c|}{ Score $\boldsymbol{g}$} & Category \\
\hline 1 & $(g)>0.7$ & High \\
\hline 2 & $0.7 \geq(g) \geq 0.3$ & Medium \\
\hline 3 & $(g)<0.3$ & Low \\
\hline
\end{tabular}

TABLE III. RECAPITUlation OF NATURAL SCIENCE PROCESS SKILlS OBSERVATION GRADE

\begin{tabular}{|l|l|l|l|l|}
\hline \multirow{2}{*}{ Description } & \multicolumn{3}{c|}{ SMPN 1 Imogiri } \\
\cline { 2 - 5 } & \multicolumn{2}{|c|}{ Experiment } & \multicolumn{2}{c|}{ Control } \\
\cline { 2 - 5 } & Initial & Latter & Initial & Later \\
\hline Average & 64 & 81.5 & 61.61 & 72.29 \\
\hline Highest Score & 75 & 88 & 70 & 78 \\
\hline Lowest Score & 50 & 73 & 45 & 67 \\
\hline Variants & 61.03 & 23.5 & 47.31 & 9.4 \\
\hline Deviation Standard & 7.81 & 4.85 & 6.87 & 3.1 \\
\hline$g$ & 0.5 & 0.28 \\
\hline Category & Medium & Low \\
\hline
\end{tabular}


From Table 3, it can be seen that the average score of the students' scientific process skills on the latter observation was higher than the initial observation, either on the experiment or control class on both schools. This case means that both classes experienced improvement. Based on the normalized gain average score analysis g, experiment class was in medium category and in control class, g grade was in the low category. $G$ grade that was obtained showed that experiment classstudents' process skills improvement was higher than control class-students' natural science process skills improvement.

The description of Students' Concept Mastery Observation Data Results can be seen in Table 4.

Based on Table 4, the difference of pre-test and post-test grades regarding concept mastery on experiment and control class of both schools could be measured. In experiment class, the students' concept mastery grade experienced a significant improvement from the average pre-test score to the post-test average score. In control class, students' concept mastery grade did not experience significant improvement.

The statistical analysis resulted from MANOVA test can be seen in Table 5. MANOVA test was carried out with a help of SPSS 16.0 for Windows program.

Based on Table 5. Sig. 0.00 was obtained, less than 0.05 which means natural science integrated local potential PLTMH learning significantly affected the students' natural science process skills and concept mastery. So, according to the research conducted in SMPN 1 Imogiri, it was known that the implementation of natural science integrated local potential PLTMH learning process significantly influenced the students' natural science process skills and concept mastery. This result was corresponding to the result of a research conducted by [21] that the use of local potential is an effective key to be used in integrated natural science learning process.

The result was significant because the learning went on naturally where the students experienced it personally through a direct observation with local potential, not just transferring

TABLE IV. RECAPITULATION OF STUDENTS' CONCEPT MASTERY GRADE

\begin{tabular}{|l|l|l|l|l|}
\hline \multirow{2}{*}{ Description } & \multicolumn{3}{c|}{ SMPN 1 Imogiri } \\
\cline { 2 - 5 } & \multicolumn{2}{|c|}{ Experiment } & \multicolumn{2}{c|}{ Control } \\
\cline { 2 - 5 } & Pre-test & Post-test & Pre-test & Post-test \\
\hline Average & 55.67 & 79.33 & 56.77 & 61.61 \\
\hline Highest Score & 70 & 100 & 70 & 85 \\
\hline Lowest Score & 45 & 65 & 40 & 45 \\
\hline Variants & 66.78 & 85.75 & 94.23 & 133.98 \\
\hline Deviation Standard & 8.7 & 9.26 & 9.7 & 11.57 \\
\hline$g$ & 0.5 & & 0.1 & \\
\hline Category & Medium & Low \\
\hline
\end{tabular}

TABLE V. ANALYSIS RESULT OF THE MANOVA TEST

\begin{tabular}{|c|c|c|c|}
\hline School & Test & Sig. & Conclusion \\
\hline SMPN 1 Imogiri & Hotelling's Trace & 0.000 & Rejected H0 \\
\hline
\end{tabular}

knowledge from teachers to the students. Besides, the learning process was balance between the learning materials in school and the local potential so that education transformation in life was corresponding to the students' necessity. The students' learning process by utilizing micro hydropower plants attracted their attention more and made them more enthusiastic in keeping up with the lessons, and also caused by how the students felt that the activity they were currently involved was an everyday activity which made their natural science process skills and concept mastery to improve was better than the class that used conventional natural science learning process.

The integration of local potential into learning in schools is heavily needed so that the students would not forget their identities and be able to develop the local potential around them. Therefore, one of the ways to implant the culture of loving local potential is through natural science learning integrated with around local potential that. According to [7], the use of local potential in learning materials is helping the student to understand the concepts correctly and contextually. Through local potential, students can learn to recognize cultural and nationalism values that might as well influence the learning outcome (attitude, habits, and thinking ability).

While according to [11], the ability to utilize the natural science process skills in overcoming everyday problems is very significant to one's personal life that is in the rapid growth of social life. According to [22], the most important target in learning is to help the students to understand the concepts, not just making them memorize separated facts. Concept mastery can be improved when a teacher is exploring a learning topic with the appropriate and deep teaching techniques, and giving interesting examples corresponding to the concept that is being taught. Hence, concept mastery is the base for forming a thinking process.

\section{CONCLUSION}

Based on the research conducted, it can be concluded that the integration of local potential into natural science learning significantly affects students' natural science process skills and concept mastery. It is because natural science learning that is integrated to local potential makes the students more active through the learning process and the learning itself goes naturally where students personally experience through direct observation with local potential, not just transferring knowledge from teachers to the students. Besides, the learning that utilizes local potential around where the students live causes the student's mastery of natural science concepts is better constructed than just memorization.

The research results showed that teacher can use local potential integrated natural science learning as an innovation in teaching to improve natural science process skills and concepts or even to measure the other variables. The integration of local potential into natural science learning process can be started by deciding a theme and the type of the local potential that will be integrated into natural science learning as an attempt to equip the students to return to the society. 


\section{REFERENCES}

[1] Mendikbud, Implementasi Kurikulum. Indonesia, 2013

[2] F. Siti and K. P. Zuhdan, Pembelajaran Sains. Yogyakarta: Penerbit Ombak, 2014.

[3] E. Richie and K. Heru, "Pengaruh Model Pembelajaran Instad Terhadap Keterampilan Proses Sains Dan Hasil Belajar Kognitif Fisika Di SMA," J. Inov. Pendidik. IPA, vol. 1, no. 2, pp. 202-211, 2015.

[4] H. Aktamis and Ö. Ergin, "The effect of scientific process skills education on students' scientific creativity, science attitudes and academic achievements," Asia-Pacific Forum Sci. Learn. Teach., vol. 9, no. 1, pp. 1-21, 2008.

[5] I. H. Wenno, "Pengembangan Model IPA Berbasis Problem Solving Method Berdasarkan karakteristik Siswa dalam Pembelajaran di SMP/MTs," J. Cakrawala Pendidik., vol. 2, no. 2, 2010.

[6] J. Holbrook, "Making chemistry teaching relevant," Chem. Educ. Int., vol. 6, no. 1, pp. 1-12, 2005.

[7] T. Laurens, C. Laamena, and C. Matitaputty, "Development a Set of Instructional Learning Based Realistic Mathematics Education and Local Wisdom," in Proceedings of International Seminar Innovation in Mathematics and Mathematics Education, 2014, pp. 571-576.

[8] S. I Wayan, Ketut, and T. Tika, "Efektifitas Model Pembelajaran Sains Berbasis Budaya Lokal untuk Mengembangkan Potensi Dasar Sains dan Nilai Kearifan Lokal di SMP," J. Penelit. dan Pengemb. Pendidik. Undiksha, vol. 5, no. 3, pp. 258-273, 2011.

[9] M. F. Syaban and I. Wilujeng, "Pengembangan SSP Zat dan Energi Berbasis Keunggulan Lokal untuk Meningkatkan Literasi Sains dan Kepedulian Lingkungan," J. Inov. Pendidik. IPA, vol. 2, no. 1, pp. 66$75,2016$.

[10] S. E. Atmojo, "Learning Which Oriented On Local Wisdom To Grow A Positive Appreciation Of Batik Jumputan (Ikat Celup Method)," $J$. Pendidik. IPA Indones., vol. 4, no. 1, pp. 48-55, 2015.

[11] B. Aydogou, M. Erkol, and N. Erten, "The investigation of science process skills of elementary school teachers in terms of some variables: Perspectives from Turkey," Asia-Pacific Forum Sci. Learn. Teach., vol. 15, no. 1, pp. 1-28, 2014.

[12] M. Tawil and Liliasari., Keterampilan - Keterampilan IPA dan Implementasinya dalam Pembelajaran IPA. Makassar: Badan Penerbit UNM, 2014.

[13] S. M. Mutisya, J. K. Too, and S. Rotich, "Performance in science process skills: the influence of subject specialization," Asian J. Soc. Sci. Humanit., vol. 3, no. 1, pp. 179-188, 2014.

[14] I. . Riya and N. Heru, "Pengembangan SSP Model SLH untuk Penumbuhkembangan Keterampilan Proses Sains dan Karakter Peduli Lingkungan Siswa,” J. Inov. Pendidik. IPA, vol. 2, no. 1, pp. 122-133, 2016.

[15] R. O. Ongowo and F. C. Indoshi, "Science process skills in the Kenya certificate of secondary education biology practical examinations," Creat. Educ., vol. 4, no. 11, p. 713, 2013.

[16] A. Widowati, Y. Wibowo, and S. Hidayati, "Pemanfaatan Potensi lokal Sekolah dalam Pembelajaran Biologi SMP," J. Pendidik. Mat. dan Sains, vol. 1, no. 1, pp. 74-82, 2013.

[17] OECD, "What 15-year-olds know and what they can do with what they know.," in PISA 2012 Results in Focus, 2014.

[18] Sukarno., P. Anna, and H. Ida, "The Profile os Science Process Skills (SPS) Student at Secondary High School (Case Study in Jambi)," Int. J. Sci. Eng. Res., vol. 1, no. 1, pp. 79-83, 2013.

[19] M. Desak Made, "Pengembangan Perangkat Pembelajaran Materi Energi pada Pemanfaatan Pembangkit Listrik Mikrohidro di Daerah Terpencil untuk Meningkatkan Keterampilan Proses dan Penguasaan Konsep Siswa di Smpn 1 Rampi Sulsel,” Universitas Negeri Yogyakarta, 2016.

[20] R. R. Hake, Analyzing Change/Gain Scores. WoodlandHills: Indiana University, 1999.

[21] R. N. Cahyaningtyas, I. Wilujeng, and I. Suryadarma, "The effect of Science Learning Based on an Integrated Scientific Approach to local Potential on the Science Process skill of the Student," Unnes Sci. Educ. J., vol. 6, no. 2, pp. 1591-1595, 2017.

[22] J. W. Santrock, Edational Psycholoy. New York: The McGraw-Hill Companies, Inc., 2011. 